\title{
Editorial
}

\section{The curriculum: What is changing?}

Dear Readers,

onventionally, the training program for postgraduates is time bound and syllabus based. It focuses on knowledge acquisition and relies on the summative assessment at the end.

Is this adequate to produce a competent professional?

The question is not new, but, becoming more relevant with mounting healthcare demands in conjunction with rapid innovations. There is a growing shift of strategy towards competency-based medical education (CBME) from traditional fixed duration of training. ${ }^{[1]}$ In this, the trainee is taught phase-wise, acquiring core procedural skills with application of knowledge and undergoes a periodic formative assessment. The tenure is flexible and extends until the trainee is competent and confident. This strategy appears to have obvious advantages, but, faces multifactorial challenges and obstacles in practical implementation, such as, lack of flexible curriculum, faculty development, higher cost, lack of uniform assessment tools, and inconsistencies in the CBME definition itself. ${ }^{[2]}$ It is at present in the introductory level and evolving. That leaves with the lone option of augmenting the existing structure into a more objective and competency based training, which is applicable uniformly across the country.

In this regard, the post-graduate education committee of the Medical Council of India (MCI), clearly defines the objectives of training, which is to produce competent specialists, who shall practice, teach and fulfil the needs to cater prevailing problems in the country related to that speciality. It is based on the established principles of learning, wherein, the student is expected to acquire knowledge (cognitive domain), professionalism (affective domain) and skills (psychomotor domain).

The major components defined by the PG medical education regulations (amended up to July 2017) are (1) Theoretical knowledge, (2) Practical and clinical skills, (3) Writing Thesis/Research articles, (4) Attitudes including communication skills and (5) Training in Research
Methodology, Medical Ethics and Medico-legal aspects. ${ }^{[3]}$ These are applicable to all the broad and superspeciality courses.

The first curriculum of plastic surgery was prepared more than 50 years ago. The effort of our excellent teachers in this regard is noteworthy. In 1964, the first Post-graduate Medical Education Conference was convened by the $\mathrm{MCI}$ under the Chairmanship of the thenUnion Minister of Health Dr. Sushila Nayyar at Delhi. It was the meeting to standardise post-graduate curriculum of different specialities. The recommendations were carefully supervised and adopted by the MCI. A group of stalwarts attended this meeting to draft the plastic surgery syllabus, which was convened by late Dr. C. Blalakrishnan. Members who contributed include Dr. N.H. Antia, Dr. R. N. Sharma, Dr. M. Mukherjee, Dr. R. N. Sinha, Dr. J. L. Gupta, Dr. Charles Pinto, Dr. R. L. Manchanda and Dr. R. K. Keshwani. ${ }^{[4]}$

Since then, the speciality has witnessed the transformation with rapid progress. The previous 2-year course is at present 3 years continuance. Currently, 193 seats of M. Ch. Plastic and Reconstructive Surgery are available in 69 medical institutions affiliated with 35 various universities/deemed universities across India. In addition, 18 institutes are offering Diplomat of National Board (D. N. B.) in Plastic Surgery. ${ }^{[4]}$ Each of these universities is guided by their own academic council leading to disparity in the curriculum.

The Association of Plastic Surgeons of India (APSI) took up the initiative to integrate the current PG guidelines of $\mathrm{MCl}$ with the existing curriculum of various universities to formulate a uniform curriculum, designed to be followed across the country. This all-encompassing document engrosses every aspect of the revised PG regulations of $\mathrm{MCI}$ beginning with eligibility, learning objectives such as theoretical knowledge, clinical and operative skills, activities of learning, teaching, research methodology, professional and personal attributes and combination of formative and summative assessment with the exit examination. It serves many purposes such as bringing all the teaching units under the solitary parameter of 
standards and achieving the objectives of PG education regulations of apex Medical Council of the country. In addition to ensuring patient safety in health care, this document serves as an authority for practitioners to withstand legal scrutiny. It is desirable and recommended to amend the curriculum periodically.

\section{Dinesh Kadam}

Deputy Editor, IJPS

Department of Plastic and Reconstructive Surgery, AJ Institute of Medical Sciences and Research Centre, Mangalore, Karnataka, India

E-mail: drkadam@yahoo.co.in

\section{REFERENCES}

1. Hawkins RE, Welcher CM, Holmboe ES, Kirk LM, Norcini JJ, Simons KB, et al. Implementation of competency-based medical education: Are we addressing the concerns and challenges? Med. Educ. 2015;49:1086-102.

2. Knox AD, Gilardino MS, Kasten SJ, Warren RJ, Anastakis DJ.
Competency-based medical education for plastic surgery: Where do we begin? Plast Reconstr Surg. 2014;133(5):702e-710e

3. Available from: https://www.mciindia.org/documents/ rulesAndRegulations/Postgraduate-Medical-Education -Regulations-2000.pdf. [Last accessed on 2017 Nov 25].

4. Available from: http://www.apsi.in/past-conferences.php. [Last accessed on 2017 Nov 25].

This is an open access article distributed under the terms of the Creative Commons Attribution-NonCommercial-ShareAlike 3.0 License, which allows others to remix, tweak, and build upon the work non-commercially, as long as the author is credited and the new creations are licensed under the identical terms.

\begin{tabular}{|l|l|}
\hline \multicolumn{2}{|c|}{ Access this article online } \\
\hline Quick Response Code: & Website: \\
\hline
\end{tabular}

How to cite this article: Kadam D. The curriculum: What is changing?. Indian J Plast Surg 2017;50:125-6. 